\title{
REMARKS, CRITICAL AND SUGGESTIVE, ON THE GENUS LIMENITIS EAST OF THE MISSISSIPPI.
}

BY ROBERT M. GREY, KENWOOD, ALBANY CO., N. Y.

Demonstrations from examples taken by me during the past three years, and from examples taken in Farmington, Conn., twenty years ago, give indubitable evidence that our Limenitis are plastic forms of one species, accommodating themselves readily to the environment, assuming colors from climatic effect or different seasons and localities, or for purposes of protection-the form $L$ disippus being mimetic of plexippus, as already suggested by authors. My conclusions are drawn from the following observations: Near the Hudson River I find ursula and proserpina in close association, each partaking of the markings of the other, evidently one brood, alighting on the same heap of pomace; expansion of wings three to three and a half inches. About six miles from the river ursula and proserpina are equally abundant, with a few arthemis and rarely a disippus. Expansion of the wings of the four about two and a half inches; all found in one glade. From this to the highest tables of the Helderberg Hills, ursula gradually disappears and only proserpina and arthemis are found, the latter most abundant. In the low lands disippus, ursula and proserpina are only found; in intermediate broken lands ursula, proserpina and arthemis are chiefly found; at the highest altitudes only proserpina and arthemis are found, and examinations of many examples from the different localities show that these forms approach each other very closely.

In December, 1877 , I sent a melanitic form of disippus to W. $\mathrm{H}$. Edwards, Esq., for his examination, and in a communication written to Mr. Edwards at the time, I ventured the assertion of all being one species. As Mr. Edwards did not notice it in a future communication, I took it as a gentle way of dealing with an absurdity. From captures made since I am convinced that all our Limenitis have one origin. In proof I have in my collection a disippus without the division line on secondaries; some with narrow and others with broad mesial lines. In one example the dividing line is extended to a broad band, with blue crescents in marginal, and red lunules in submarginal band. An arthemis from the white band to margin is the exact counterpart of it; in one example, on the under surface of secondaries inside of mesial line, are white lunules. 
I have a melanitic form of disippus with all the markings of ursula on the under surface, and an ursula that mimics this at the apex of superior wings, and is suffused with tawny red to base of wing. One ursula has a bright red under surface, and so on through many examples blending into each other in color, proving all to be of one origin. The larva feed on much the same food plants. The larve of disippus and ursula are held by many collectors to be undistinguishable.

\section{ANOTHER BEE ENEMY.}

BY A. J. COOK, LANSING, MICHIGIN.

About one year ago I received a small bug from a gentleman in Maryland, together with the information that it was a serious enemy of the honey bee. It was stated that this bug would lie concealed among the flowers, and upon occasion would grasp a bee, and, holding it off at arm's length, would suck out its blood and life. More recently, I have heard of the same insect, with the same habits, in Iowa, Missouri, Illinois, and more recently, through the editor of Gleaningrs, from Minnesota, and later still, from V. W. Keeney, Shirland, Ill. In one case it was stated that the bug had the power, which it was not slow to use, of stinging quite severely. This same insect has been observed by both Prof. W. J. Beal and myself, at this place, resting on flowers, in which it is often almost concealed, awaiting an opportunity to capture and defluidize its prospective victims.

\section{WHAT IS IT?}

This is a Hemipteron, or true bug, and belongs to the family Phymatida Uhr. It is the Phymata erosa, Fabr., the specific name erosa referring to its jagged appearance. It is also called the "stinging bug," in reference to its habit of repelling intrusion by a painful thrust with its sharp, strong beak.

\section{BIBLIOGRAPHY.}

This insect is mentioned by the lamented Dr. B. D. Walsh (Am. Entomol., vol. r, p. I4 ), who facetiously compares its intelligence with 